\title{
Towards a lower prevalence of Oestrus ovis infections in sheep in a temperate climate (south west France)
}

\author{
Philippe JACQUIET*, Philippe DorChIES
}

\begin{abstract}
UMR INRA/ENVT 959, Physiopathologie Infectieuse et Parasitaire des Ruminants, École Nationale Vétérinaire, 23 chemin des Capelles, 31076 Toulouse, France
\end{abstract}

(Received 21 November 2001; accepted 26 February 2002)

\begin{abstract}
Oestrus ovis larvae are obligatory parasites of the nasal and sinus cavities of sheep and goats. In the temperate climate of western Europe, fly attacks occur between May and October and the first stage larvae arrest their development within the host between October and February. Oestrosis clinical signs such as nasal discharge and sneezing are well known by sheep breeders in southwest France. According to veterinarian recommendations, most of them treat their animals with long lasting fasciolicides once a year at least, mainly during the fly activity period and at the beginning of the hypobiotic period (when the parasitic population is only constituted of larvae). The consequences of these therapeutic programs were analysed in a local slaughterhouse by larval counts. Both prevalence and intensities of O. ovis infections decreased between 1989-1991 (before the use of systematic treatments) and 1996-1998 (after the spread of these treatments). The use of systematic treatments during the fly activity period and the beginning of the hypobiotic period seems to be very efficient in $O$. ovis control and could theoretically lead to a possible 'eradication' program as with cattle hypodermosis. Nevertheless the presence of parasites in apparently healthy goats, the possibility for a fly generation to develop before the first treatment in July-August and the succession of several fly generations all around the year in southern Mediterranean and tropical countries will maintain $O$. ovis infections. Furthermore, there are increased concerns about drug residues on consumer health and environment and this is the basis for the prospect of alternative strategies in $O$. ovis control.
\end{abstract}

\section{Oestrus ovis / sheep / goat / systematic treatment / prevalence /}

Résumé - Vers une diminution de la prévalence des infestations par Oestrus ovis chez le mouton en climat tempéré (Sud Ouest de la France). Les larves d'Oestrus ovis sont des parasites obligatoires des cavités nasales et sinusales des moutons et des chèvres. Dans les climats tempérés d'Europe de l'Ouest, les attaques des mouches adultes ont lieu entre mai et octobre et le premier stade larvaire arrête son développement chez l'hôte entre octobre et février. Les signes cliniques comme le jetage et les éternuements sont bien connus des éleveurs du sud ouest de la France. Selon les recommandations

\footnotetext{
* Correspondence and reprints

Tel.: (33) 5611939 67; fax: (33) 5611939 44; e-mail: p.jacquiet@envt.fr
} 
des vétérinaires praticiens, beaucoup d'entre eux traitent leurs animaux avec des produits rémanents comme le closantel, une ou deux fois par an, pendant la période d'activité des mouches et au début de la période d'hypobiose. Les conséquences de ces programmes de chimioprévention ont été analysées lors d'enquêtes en abattoirs. La prévalence et l'intensité des infestations par $O$. ovis chez les ovins ont diminué entre 1989-1991 (soit avant la mise en place de ces programmes) et 1996-1998 (soit après la diffusion et l'application de ces programmes). L'utilisation systématique de traitements rémanents pendant la période d'activité des mouches adultes semble très efficace dans le contrôle des populations d'O. ovis et pourrait même conduire à une « éradication » de ce parasite comme dans le cas de l'hypodermose bovine. Toutefois, le refus de certains éleveurs d'appliquer ces traitements, l'infestation silencieuse des chèvres et la possibilité pour une première génération de mouches de se développer avant le premier traitement de juillet-août limitent l'efficacité de ces mesures. De plus, l'intérêt croissant des pouvoirs publics et des consommateurs pour les résidus médicamenteux dans les produits d'origine animale conduit à envisager des solutions alternatives pour le contrôle des populations d'O. ovis.

\section{Oestrus ovis / mouton / chèvre / traitement systématique / prévalence}

\section{INTRODUCTION}

Oestrus ovis larvae are obligatory parasites of the nasal and sinus cavities of sheep and goats $[10,17]$. First instar larvae (L1) are deposited on the nostrils of the host by female flies, and penetrate actively into the nasal cavities. Then, L1 migrate to the ethmoid to molt to second instar larvae (L2). In the sinus, L2 larvae molt to third instar larvae (L3) which are sneezed by the host onto the ground where they pupate. Adult flies have a reduced and nonfunctional oral apparatus, and so are not able to feed. Thus larvae, in close contact with mucosa, play an essential role in accumulating nutrients for the free stages of the life cycle. In the temperate climate of western Europe, adult flies are active from May-June to September-October. The length of the parasitic portion of the life cycle is quite variable lasting from 3-4 weeks [4] to several months depending on the season and climatic conditions $[15,16]$. In the summer, rapid larval development occurs whereas L1 arrested development (L1 hypobiosis) takes place in the late autumn and winter and corresponds to a survival within the host during the period of the year defavourable to the adult fly activity. The hypobiotic first stage larvae represent the totality of $O$. ovis populations during the winter. From February to April, larvae resume their development and newly hatched flies are seen in May-June. In southern Mediterranean countries (Morocco, Tunisia, etc.), the hypobiosis period is shorter and in humid tropical countries, adult fly activity and larval development occur all around the year [13].

Oestrosis is a widespread myiasis which may severely impair the health of small ruminants. The presence of $O$. ovis larvae leads to strong inflammation $[6,11]$ in the summer (with mucus hypersecretion and nasal discharge in response to numerous larval depositions by adult flies) and in late winter (sinusitis in response to the rapid development of larvae at the end of the hypobiosis period). In addition to these local effects, some indirect effects such as lung abscesses and interstitial pneumonia are not rare [3]. According to breeders, goats are not heavily infected and oestrosis is only a sheep disease despite the common presence of the parasites in goats [7].

The current method of oestrosis control is chemotherapy in sheep because no baits and no traps are available to control the free living adult flies [2]. Furthermore, control by sheep immunisation is still in its infancy [9]. Endectocide and fasciolicide drugs 
such as closantel and nitroxynil are used to treat oestrosis in sheep and goats $[5,8,12]$.

The aim of this paper is to demonstrate that it is possible to considerably lower the prevalence and the intensity of natural ovine oestrosis by regular drug treatments during the grazing period.

\section{MATERIALS AND METHODS}

Lactating ewes in the central Pyrenees are reared for lamb production. They pasture all year round and are naturally submitted to $O$. ovis infections from May to October. Owing to the long lasting activity of closantel against $O$. ovis larvae (more than six weeks), Alzieu et al. [1] proposed two treatments with this drug $(10 \mathrm{mg} / \mathrm{kg})$ during the summer, two months apart (July and September) and demonstrated in a field trial that a significant reduction of $O$. ovis populations $(>98 \%)$ and an improvement of sheep health occurred in the treated group compared to the non treated one. This preventive program has been strongly recommended to sheep breeders in the Pyrenean area of southwest France and has been largely adopted.

Regular visits to the slaughterhouse of Pamiers (Ariège, southwest France close to the Spanish border) allowed the collection of 744 sheep heads during the years 1989-1991 (419 during the hypobiosis period i.e. from October to January and 325 during the end of the hypobiotic period i.e. from March to June) and 400 sheep heads during the years 1996-1998 (268 and 132 respectively). No systematic treatments were done against oestrosis during the years 1989-1991 whereas the strategic program with two administrations of closantel, two months apart, was largely used during the years 1996-1998. The slaughterhouse of Pamiers is small and collects only sheep coming from the Pyrenean area of Ariège. The same cranial examination procedure, previously validated [15], was used in the
1989-1991 and 1996-1998 periods. Briefly, sagittal sections of each head were made and larvae were collected from the five major sites (nasal cavities, septum, middle meatus, conchae and sinuses). Larvae were counted and identified to instar under a stereomicroscope using the keys of Zumpt [17]. Comparisons between sheep $O$. ovis prevalences were performed with the chi-square test (Stat ITCF Software, France, 1991) and comparisons were made between $O$. ovis larval burdens using the non-parametric Kruskall Wallis and MannWhitney tests (Simstat Software, Canada, 1992).

\section{RESULTS}

Comparisons of prevalences and intensities of $O$. ovis infections between the two periods (1989-1991 and 1996-1998) are shown in Table I. Concerning the hypobiosis period of the $O$. ovis life cycle, highly significant decreases in prevalence $(-23 \%)$ and in mean larval burden $(-58 \%)$ were observed between the years 1989 to 1991 and 1996 to 1998 . The difference of prevalence was not significant with data collected from March to June, whereas the difference of mean larval burden was significant $(P<0.05)$. A significant reduction in infection intensity was observed and was linked to the increasing parasiticide treatments.

\section{DISCUSSION}

Many environmental factors can affect the prevalence and intensity of $O$. ovis infections in sheep and interannual variations are not rare. Nevertheless, the present survey took three years into account to compare before and after the spread of strategic treatments in the Pyrenean area in order to minimise this phenomenon. Moreover, no dramatic annual variations were observed 
Table I. Evolution of the prevalence and intensities of Oestrus ovis infections in southwest France (slaughterhouse of Pamiers) between 1989-1991 (before the use of strategic treatments) and 1996-1998 (after the use of strategic treatments).

\begin{tabular}{|c|c|c|c|c|c|c|}
\hline \multirow[b]{2}{*}{ Period } & \multicolumn{3}{|c|}{$\begin{array}{l}\text { Hypobiosis period } \\
\text { (October to January) }\end{array}$} & \multicolumn{3}{|c|}{$\begin{array}{l}\text { End of hypobiosis period } \\
\text { (March to June) }\end{array}$} \\
\hline & $\begin{array}{l}\text { No. of sheep } \\
\text { examined }\end{array}$ & $\begin{array}{c}\text { Prevalence } \\
\text { of } O . \text { ovis } \\
\text { infections } \\
(\%)\end{array}$ & $\begin{array}{l}\text { Mean } \\
\text { intensity of } \\
\text { infections }\end{array}$ & $\begin{array}{l}\text { No. of sheep } \\
\text { examined }\end{array}$ & $\begin{array}{c}\text { Prevalence } \\
\text { of } O . \text { ovis } \\
\text { infections } \\
(\%)\end{array}$ & $\begin{array}{c}\text { Mean } \\
\text { intensity } \\
\text { of infections }\end{array}$ \\
\hline $\begin{array}{l}\text { Years } \\
1989-1991\end{array}$ & 419 & 60.1 & 29.7 & 325 & 48.3 & 13.1 \\
\hline $\begin{array}{l}\text { Years } \\
1996-1998\end{array}$ & 268 & 46 & 12.6 & 132 & 41.7 & 4.54 \\
\hline $\begin{array}{l}\% \text { of } \\
\text { reduction }\end{array}$ & - & 23 & 58 & - & 14 & 65 \\
\hline $\begin{array}{l}\text { Statistical } \\
\text { significance }\end{array}$ & - & $P<0.001$ & $P<0.01$ & - & NS & $P<0.05$ \\
\hline
\end{tabular}

in each of the two periods of the survey (data not shown). Of course, many sheep breeders of Ariège did not strictly apply the treatment protocol (although most of them did), therefore, the observed differences should be less important than those expected previously. It is known that marked flies released in sheep pens survive for up to 37 days and remain at the released site or reach sheep pens up to $6 \mathrm{~km}$ away as well [14]: external reintroductions of $O$. ovis can occur very easily in well-treated sheep flocks. Considering this risk, the O. ovis infections were highly reduced between (1989-1991) and (1996-1998): this could be a consequence of the intensive use of effective drugs during the summer (when numerous flies lay first stage larvae on sheep) and during the beginning of the hypobiotic period. The persistence of $O$. ovis infections in Pyrenean sheep flocks can be explained by several factors. Some sheep breeders do not treat their animals during the summer and/or autumn. Usually, farmers treat their animals when clinical signs are severe, however the first spring infec- tions or reinfections are not associated with overt nasosinusal clinical signs. Recent findings from experiments with tracer lambs showed that low grade infections occur in the spring [4]. The absence of reaction associated with spring infection may be due to the low larval dose received which may be under a 'reaction' threshold. Nasal discharges and sneezing are often evident a month or two after the primary attack when the second or third fly generations are active. Goat oestrosis is rarely treated in France because goats are less severely affected than sheep, therefore, goats could represent a refuge for the parasites.

The use of long lasting fasciolicides can lead to a general decrease of both prevalence and intensities of Oestrus ovis infections in sheep. Regarding hypodermosis control in cattle, there is a theoretical possibility of $O$. ovis eradication in areas where L1 hypobiosis occurs in the winter if concerted control programs are decided and applied by all breeders in the field. Thus, the differences in seasonal patterns of $O$. ovis 
populations according to the climate present an important outcome concerning the control of this parasitosis: in countries where hypobiosis is present, large scale systematic treatments in late autumn or winter could be of great interest. On the contrary, in countries where $O$. ovis infections occur all year round as in tropical countries, strategic treatments seem to be of less interest.

Moreover, concerns about the effects of drug residues on consumer health and the environment have focussed attention on the prospect of developing alternative control strategies. As mentioned previously, no baits and no traps are available for adult Oestrus ovis. Immunisation of sheep with excretory-secretory products of larvae do not protect against larval establishment but provide a transitory inhibition of larval growth [9]. At present, the most feasible and practical alternative approach is to keep the sheep indoors during the warmest hours of the day between July and September. This strategy seems to be very effective in the Atlantic Pyrenees (data not shown): sheep breeders do not observe clinical signs in their flocks when using this management strategy.

\section{REFERENCES}

[1] Alzieu J.P., Dorchies P., Donat F., Chiarisoli O., Données nouvelles sur l'épidémiologie de l'oestrose ovine et sa prévention par le closantel, Le Point Vétérinaire 26 (1994) 63-69.

[2] Cepeda-Palacios R., Scholl P., Factors affecting the larvipositional activity of Oestrus ovis gravid females (Diptera: Oestridae), Vet. Parasitol. 91 (2000) 93-105.

[3] Dorchies P., Yilma J.M., Savey M., Lung involvement in ovine oestrosis: prevalence of lung abscesses and interstitial pneumonia, Vet. Rec. 133 (1993) 325.

[4] Dorchies P., Duranton C., Bergeaud J.P., Alzieu J.P., Chronologie de l'évolution naturelle des larves d'Oestrus ovis (Linné 1761) chez l'agneau non immunisé, Bull. Soc. Fr. Parasitol. 14 (1996) 20-27.
[5] Dorchies P., Alzieu J.P., Cadiergues M.C., Comparative curative and preventive efficacies of ivermectin and closantel on Oestrus ovis (Linné $1761)$ in naturally infected sheep, Vet. Parasitol. 72 (1997) 179-184.

[6] Dorchies P., Duranton C., Jacquiet P., Pathophysiology of Oestrus ovis infection in sheep and goats: a review, Vet. Rec. 142 (1998) 487-489.

[7] Dorchies P., Bergeaud J.P., Tabouret G., Duranton C., Prévot F., Jacquiet P., Prevalence and larval burden of Oestrus ovis (Linné 1761) in sheep and goats in northern Mediterranean region of France, Vet. Parasitol. 88 (2000) 269-273.

[8] Dorchies P., Jacquiet P., Bergeaud J.P., Duranton C., Prévot F., Alzieu J.P., Gosselin J., Efficacy of doramectin injectable against Oestrus ovis and gastrointestinal nematodes in sheep in the southwestern region of France, Vet. Parasitol. 96 (2001) 147-154.

[9] Frugère S., Cota-Leon A., Prévot F., Cepeda-Palacios R., Tabouret G., Bergeaud J.P., Duranton C., Dorchies P., Jacquiet P., Immunisation of lambs with excretory-secretory products of Oestrus ovis third instar larvae and subsequent experimental challenge, Vet. Res. 31 (2000) 527-535.

[10] Hall M., Wall R., Myiasis of humans and domestic animals, Adv. Parasitol. 35 (1995) 257-334.

[11] Nguyen V.K., Bourges N., Concordet D., Dorchies P., Mastocytes et éosinophiles de la muqueuse respiratoire du mouton infesté par Oestrus ovis (Linné 1761), Parasite 3 (1996) 217-221.

[12] Puccini V., Giangaspero A., Fasanella A., Efficacy of moxidectin against Oestrus ovis larvae in naturally infested sheep, Vet. Rec. 135 (1994) 600-601.

[13] Tabouret G., Jacquiet P., Scholl P., Dorchies P., Oestrus ovis in sheep: improvement in control through knowledge of relative third-instar populations, Vet. Res. 32 (2001) 525-531.

[14] Ternovoi V.I., Mikhailenko V.K., On the flight range of the sheep nostril fly Oestrus ovis, Parazitologiya 7 (1973) 123-127.

[15] Yilma J.M., Contribution à l'étude de l'épidémiologie, du diagnostic immunologique et de la physiopathologie de l'oestrose ovine (Oestrus ovis Linné 1761). Thèse de l'Institut National Polytechnique de Toulouse, 1992, 219 pp.

[16] Yilma J.M., Dorchies P., Epidemiology of Oestrus ovis in southwest France, Vet. Parasitol. 40 (1991) 315-323.

[17] Zumpt F., Myiasis in man and animals in the old world, Butterworths Editions, London, 1965, $225 \mathrm{pp}$. 